\title{
Forskningsbaseret undervisning i UC-sektoren - hvad og hvordan?
}

Peter Sørensen, lektor, University College Lillebælt, Malene Slott, lektor, University College Lillebælt og Søren Harnow Klausen, professor, Institut for

kulturvidenskaber,

Syddansk

Universitet

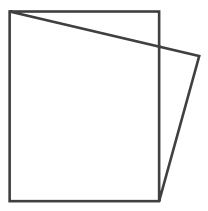

De danske University Colleges (herefter "UC'er") skal levere forskningsbaseret undervisning. Det fremgår af UC'ernes bekendtgørelse. Men det fremgår ikke, hvad der skal forstås ved forskningsbaseret undervisning, hvordan UC'erne kan arbejde med forskningsbaseret undervisning, og hvordan UC'ernes arbejde med forskningsbaseret undervisning adskiller sig fra universiteternes. Derfor søger vi forst i denne artikel at besvare, hvordan begrebet 'forskningsbaseret undervisning' defineres både i den nationale og internationale litteratur. Derefter giver vi et bud på, hvad der kan forstås ved forskningsbasering specifikt i relation til UC-sektoren, og hvordan man reelt kan arbejde med forskningsbaseret undervisning. Vi viser, at der dels er forskel på universiteternes og UC'ernes forståelse af at arbejde med forskningsbaseret undervisning, dels at UC'erne af 'natur' er forbilledlige i den henseende, idet UC'erne har et klart fokus på løsningen af konkrete samfundsopgaver med tætte bånd til aftagerinstitutioner og med tradition for at kombinere praktiske og teoretiske uddannelseselementer.

\section{Indledning}

Forskningsbaseret undervisning har traditionelt været forbeholdt universiteterne, men med dannelsen af de danske UC'er i 2008 og senere bekendtgørelser (seneste fra 2014) er det blevet et lovkrav, at de aktivt skal "medvirke til, at ny viden tilvejebringes og bringes i anvendelse i såvel den private som den offentlige sektor" (LBK, nr. 936,§3). UC'erne skal altså være forskningsproducerende og udbyde forskningsbaseret undervisning. De har pligt til at "udbyde og udvikle videregående uddannelse og at varetage praksisnære og anvendelsesorienterede forsknings- og udviklingsaktiviteter" (ibid.), ligesom det hedder, at "professionshøjskolernes uddannelser skal bygge på forsknings- og udviklingsviden" (ibid, §4). Dermed indskrives de i den uddannelseskontekst, som arbejder med forskningsbaseret undervisning. Måske udviskes også den forskel, der hidtil har været mellem UC'erne og universiteterne?

I årene op til dannelsen af UC'erne skrev Torben K. Jensen i det første nummer af Dansk Universitetspœdagogisk Tids- 
Forskningsbaseret undervisning i UC-sektoren - hvad og hvordan?

skrift (DUN, 2006), at "[e]n afgørende forskel på universitetsundervisning og anden undervisning ligger $i$, at den [universitetsundervisningen, ff.] er forskningsbaseret". Dette, skriver han, indebærer bl.a. at:

- undervisningen foregår på forskningsinstitutioner;

- det er forskere, der underviser, for til stadighed at sikre, at undervisningen er på højeste faglige niveau;

- undervisningen ikke bare tager sigte på, at de studerende erhverver ny viden, men også på, at de studerende bliver i stand til at producere ny viden;

- undervisning omhandler i reglen både et videnskabsfags empiri, teori, metode og videnskabsteoretiske grundlag (DUN, 2006, 2).

Eftersom bekendtgørelsen for UC'erne (LBK 936) fastslår deres pligt til at varetage forsknings- og udviklingsaktiviteter, og at de anno 2016 er godt i gang med den videns- og kapacitetsopbygning, som er nødvendig for at kunne påtage sig deres forpligtelse som forskningsinstitutioner, er UC'erne imidlertid stærkt på vej til kunne leve op til de samme fire krav, der ifølge Torben K. Jensen karakteriserer forskningsbaseret undervisning på universiteterne. Men da UC'er og universiteter indtil videre opretholdes som selvstændige uddannelses- og forskningsinstitutioner, er det nærliggende at diskutere, hvad der egentlig kan forstås ved forskningsbaseret undervisning i en UC-sektor. UC'erne kan ikke blot kopiere universiteternes forståelse af forskning og forskningsbaseret undervisning, idet både uddannelseslængde og formålsparagraffer er forskellige. Bl.a. hedder det, at UC'erne har en særlig forpligtelse til at arbejde med praksisnær og anven- delsesorienteret forskning (LBK, nr. 936, §3). Det betyder, at UC'erne skal give undervisning baseret på anvendt forskning, men det betyder også, at vidensproduktionen på UC'erne (stadig) delvist bedømmes efter andre kriterier end de rent akademiske.

Ser man bort fra, at universiteterne for længst er blevet storleverandører af anvendt forskning og også på andre måder vekselvirker med det omgivende samfund, fremstår det som et klart eksempel på forskellen mellem modus 1- og modus 2-forskning (EVA, Nowotny, Scott et al. 2006). Med kravet om at skulle basere undervisningen på anvendt forskning står UC'erne midt i det krydsfelt, hvor forskning og praksis mødes. UC'erne uddanner professionelle praktikere og skal bedrive forskning, der kan være med til at forbedre praksis. Derfor skal de også give undervisning, der er baseret på den forskning, som kan og bliver anvendt i praksis. Men hvad skal der nærmere forstås ved undervisning, som er baseret på anvendt forskning? Hvordan kan forskning anvendes i undervisning? Og hvordan kan undervisning og forskning gensidigt befrugte hinanden $i$ UC-sektoren? Det er, hvad vi vil diskutere i denne artikel, hvor vi søger svar på to spørgsmål:

1. Hvad er forskningsbaseret undervisning?

2. Hvordan kan man arbejde med forskningsbaseret undervisning $i$ UC-sektoren?

Spørgsmålene søges besvaret ved først at se på, hvordan OECD definerer forskning. Dernæst diskuteres det, hvad der kan forstås ved forskningsbaseret undervisning, og det beskrives, hvorfor UC'erne netop nu retter blikket skarpt mod den forskningsbaserede under- visning. I anden del af artiklen giver vi et bud på, hvordan man kan arbejde med forskningsbaseret undervisning $i$ UC-sektoren.

\section{Hvad er forskningsbaseret undervisning?}

De danske uddannelses- og forskningsinstitutioner anvender officielt OECD's definition på forskning (ufm.dk). Ifølge OECD's Frascati-manual (2002) defineres forskning og udvikling "som skabende arbejde foretaget på et systematisk grundlag der har til hensigt at øge den eksisterende viden, samt at udnytte denne viden til at udtænke nye anvendelsesområder" (Frascati, p. 30). Universiteterne har pligt til at bedrive forskning, som øger den eksisterende viden, og de har pligt til at anvende denne viden til at udtænke nye anvendelsesområder, som kan bidrage til at fremme vækst, velfærd og udvikling i samfundet (LBK nr. 261, §2, stk.3).

Traditionelt har universiteternes hovedfokus været grundforskning - altså forskning, som er eksperimenterende og har det primære formål at opnå ny viden og forståelse uden nogen bestemt anvendelse i sigte (ufm.dk). Det har i hvert fald været kendetegnende for universiteternes selvforståelse, selv om de i praksis har været knyttet til løsningen af konkrete samfundsopgaver, f.eks. uddannelsen af embedsmænd med ganske bestemte kompetencer, og selv om ideen om universitet som vidensproducerende institution er af forholdsvis ny dato (se fx Clark 2006) og længe blev mødt med skepsis. Således afviste kardinal Newman, hvis ideer har præget universitetsuddannelserne i den engelsktalende verden, at forskning hører hjemme på et universitet, med den begrundelse at de som uddannelsesinstitutioner alene bør 
Tema: Kultur og civilisering

sigte på at formidle den eksisterende viden på den pædagogisk bedste vis (Newman, 1852/1873).

I de sidste ti år er der imidlertid også stillet krav til universiteterne om at bedrive praksisnær og anvendelsesorienteret forskning, som netop er det, der kendetegner UC'ernes 'nye' forskningsforpligtelse. Hvad enten institutionerne bedriver grundforskning og/eller anvendt forskning, så er det forskningen, som skal lægges til grund for undervisningen, når både universiteter og UC'er skal bedrive forskningsbaseret undervisning. Men hvordan denne forskningsbasering kan forstås, gives der en række forskellige bud på i den nationale og internationale litteratur.

En måde at forstå begrebet forskningsbaseret undervisning på, er at "undervisningen bygger på forskningsresultater" (Ulriksen 2014, p. 136).

Det virker nærmest selvindlysende, at forskningsbaseret undervisning er undervisning, som er baseret på forskning. Men ved nærmere eftertanke siger forklaringen ikke så meget. Hvis man med begrebet 'bygger på' forstår, at man anvender og/eller inddrager forskningsresultater i undervisningen, så bygger næsten al undervisning på alle typer af uddannelsesinstitutioner på forskningsresultater. Undervisningen på en teknisk skole bygger på forskning i fysik, kemi, elektronik og utallige andre emner. Undervisningen i en folkeskole bygger bl.a. på pædagogiske, psykologiske og didaktiske forskningsresultater; og selv om indholdet ofte er blevet forenklet, stammer det meste jo også indirekte fra en form for forskning. Undervisningen på en aftenskole bygger måske på forskningsresultater indenfor musikviden- skab, litteraturvidenskab og antropologi. Det gør jo ikke nødvendigvis disse tre typer af undervisningsinstitutioner til steder, som bedriver forskningsbaseret undervisning.

En anden måde at forstå begrebet forskningsbaseret undervisning er, at det er undervisning, som kan karakteriseres ved, at den overvejende del af undervisningen varetages af aktive forskere. I den engelsksprogede litteratur kaldes det ofte 'research-led teaching' (Willcoxson 2011, Brew 2012), hvilket i en dansk kontekst ofte benævnes 'forskningsinformeret undervisning' (se fx Qvortrup 2015). Hvis man forfølger den forklaring, så vil der være noget undervisning på eksempelvis universiteterne, der er forskningsbaseret, medens anden undervisning ikke er det. Således vil undervisning, som varetages af instruktorer og timelærere ikke være forskningsbaseret, medens den undervisning, der varetages af ph.d.-uddannede vil være forskningsbaseret.

En tredje måde at forstå forskningsbasering på vedrører forskertilrettelagt undervisning. Akkrediteringsbestemmelserne for universitetsuddannelserne rummer et krav om, at der skal være et "anerkendt, internationalt forskningsmiljø omkring uddannelsen", samt at uddannelse og undervisning skal være "tilrettelagt af forskere" (ACE Denmark, 2011). Det kan virke pudsigt, at der stilles krav til det, der skal være omkring uddannelsen og undervisningen, altså de formelle rammer for den, snarere end til undervisningen selv. Men rationalet er formentlig en formodning om, at det ikke er realistisk eller hensigtsmæssigt at kræve, at al undervisning skal udføres af forskere, samt en idé om at forskere vil kunne gennemføre en overordnet kvalitetssikring af undervisningen ved at tilrettelægge den. De meget lempelige bestemmelser viser dog, at forestillingen om, at universitetet grundlæggende udmærker sig i forhold til andre uddannelsesinstitutioner i kraft af sin forskningsbasering, ikke nødvendigvis har hold i virkeligheden.

En fjerde måde at forstå begrebet forskningsbaseret undervisning på er, at kun den undervisning, som varetages af forskere indenfor det fag, som der undervises i, strengt taget kan siges at være forskningsbaseret (Videnskabernes selskab, p.7). Argumentet for denne forståelse er, at kun forskere inden for et givet fag kender fagets metoder og nyeste teorier tilstrækkeligt grundigt til, at undervisningen kan kaldes forskningsbaseret. Den har imidlertid som konsekvens, at langt størstedelen af undervisningen på landets universiteter og UC'er ikke kan siges at være forskningsbaseret - selvom begge uddannelsesinstitutioner kaldes forskningsbaserede. Årsagen er, at der er mange undervisere, der, selvom de er aktive forskere, underviser $\mathrm{i}$ andet end netop det, de selv forsker $i$.

Et femte bud på en begrebsbestemmelse forholder sig til sammenhængen mellem forskning og undervisning (the researchteaching nexus) på en anden måde.

Den undervisningsform, som på dansk går under betegnelsen problembaseret læring, forstås bredere i den engelsktalende del af verden, hvor den også inkluderer forskellige teoretiske tilgange. Disse undervisningsformer benævnes eksempelvis constructivist, discovery, experiential eller inquiry-based teaching (herunder også Problem Based Teaching and Learning), og de tager sigte på at 


\section{Med kravet om at skulle basere undervisningen på anvendt forskning står UC'erne midt i det krydsfelt, hvor forskning og praksis mødes.}

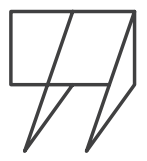

indføre de studerende i forskningens forskellige discipliner, metoder og tænkemåde ved at anvende et begrænset mål af instruktion og i stedet lade de studerende søge, drøfte og eksperimentere sig frem (Kirschner et al. 2006).

Som det forhåbentligt er fremgået, er det eneste, som de fem forskellige tilgange har tilfælles, at de alle - men fra hver sin vinkel - beskriver mulige sammenhænge mellem begreberne forskning og uddannelse. Men hvis begrebet forskningsbaseret undervisning ikke lader sig entydigt bestemme, er man måske nødt til, i hver enkelt kultur, på sektorniveau og/eller eventuelt på hver enkelt uddannelsesinstitution at bestemme sig for, hvordan man forstår, definerer og arbejder med begrebet forskningsbaseret undervisning. Vi har valgt at se på, hvordan det kan gøres i UC-sektoren og starter med at skitsere den aktuelle, samfundsmæssige kontekst, set fra et UC perspektiv, der udtrykker konkrete anledninger til at skærpe den forskningsbaserede undervisning.
Der har været ph.d.'ere i UC-sektoren i mange år. De har enten været ansat i UC'ernes forskningsafdelinger, hvor de har ledet forsknings- og udviklingsaktiviteter i samarbejde med praksis, eller de har været ansat til at undervise (som adjunkter/lektorer, jf. UC-sektorens stillingsstruktur) på lige fod med UC'ernes andre undervisere, der typisk har en baggrund som kandidater og/ eller professionsbachelorer. Tilstedeværelsen af forskeruddannede undervisere har imidlertid ikke kunnet imødegå en skarp kritik af undervisningskvaliteten på professionshøjskolerne (se fx uc-dk. dk, Altinget.dk, DenOffentlige.dk). Disse forhold er UC-sektoren opmærksom på (http://danskeprofessionshøjskoler.dk/), ligesom der i resten af det danske uddannelsessystem generelt er stor opmærksomhed på de samfundsmæssige krav til både kvalitet, økonomi og indhold.

Dette viser sig bl.a. ved, at UC'erne - i samarbejde med erhvervsakademierne, universiteterne, de kunstneriske og kulturelle uddannelser og uddannelses- og forskningsministeren - har iværksat en række initiativer, der bl.a. skal medvirke til øget kvalitet (http://ufm.dk/). Initiativerne er organiseret i temaer, hvoraf to af dem kan blive særlige betydningsfulde i UC-sektoren. Det første tema drejer sig om Fœlles ansvar for studier på fuld tid, hvori det specificeres, at der skal være "ambitiøse krav til det faglige niveau" (s. 3). Disse ambitiøse krav til det faglige niveau kan fx omsættes som et skærpet behov for dygtigere undervisere, fx i form af forskeruddannede undervisere. Det andet tema er $\varnothing$ get indsats for bedre praktik og mere relevante uddannelser, hvori det specificeres, at "studerende på alle uddannelser skal tilegne sig kompetencer, der ruster dem til krav og forventninger på arbejdsmarkedet. Bl.a. ved at deres viden i større omfang sættes på spil i virkelighedsnære problemstillinger" (s. 4). Dette udsagn står også centralt i UC'ernes formålsparagraf, som nævnt ovenfor, og det betyder også, at når universiteterne bevæger sig ind i praksisfelterne, så udlignes UC'ernes særkende på dette område. 


\section{I de sidste ti år er der imidlertid også stillet krav til universiteterne om at bedrive praksis- nær og anvendelsesorienteret forskning, som netop er det, der kendetegner UC'ernes 'nye' forskningsforpligtelse.}

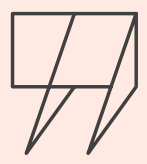

I forhold til økonomi og indhold er den politiske opmærksomhed rettet mod dels statens udgifter til uddannelsessektoren på den ene side, og dels på et arbejdsmarked i forandring på den anden side. I regeringens kvalitetsudvalg blev der derfor lagt op til, at færre studerende skal uddannes på kandidatniveau lige som universiteternes bacheloruddannelser skal gøres mere erhvervsrettede (http://ufm.dk/). Det skal ske ved, at universiteternes nuværende bacheloruddannelser omdannes til 4-årige akademiske bacheloruddannelser med forskellige toningsmuligheder i det fjerde år, hvor fokus på fagets praktiske anvendelsesmuligheder er en af dem (http://danskeprofessionshøjskoler.dk/). Dette forslag kan derfor ligeledes bidrage til at udligne UC'ernes særkende.

Sammenfattende kan det siges, at UC-sektoren er udfordret på uddannelseskvaliteten, samtidig med at universi- teterne har fået øje på praksisfeltet og nye uddannelsesmuligheder i tilknytning til fremtidige beskæftigelsesmuligheder på arbejdsmarkedet - både af egen drift og som følge af et hårdt politisk pres. Det er i dette scenarie, at forskekompetencer kan bidrage til at styrke UCsektoren.

\section{Hvordan kan man arbejde med} forskningsbaseret undervisning i UCsektoren? Et tentativt bud på et svar Der er allerede iværksat initiativer med henblik på at kapacitetsopbygge forskningssiden. Det kan fx aflæses i den nye $\mathrm{PH}$-stillingsstruktur, hvor det nu er muligt at få titel af docent, hvilket indikerer en styrkelse af professionshøjskolernes forskningskvalitet. Hvis UC-sektoren derudover vælger at understøtte samarbejdet med UCgrunduddannelserne og på området for efter- og videreuddannelse, så kan den systematiske videnopbygning bidrage til at øge det faglige niveau i undervisningen inden for alle områder.

Det skyldes, at forskningskompetente undervisere er i stand til at forholde sig kritisk og systematisk til den viden, vidensgenerering og vidensformidling, som vedkommende lægger til grund for og anvender i sin undervisning. De har solid viden om, hvad der karakteriserer viden, og hvordan viden skabes, dvs. et videnskabsteoretisk fundament, ligesom de har et solidt kendskab til forskellige forskningsmetoder, og til hvordan og i hvilket omfang forskellige metoder kan bidrage til både at generere og at indsamle viden. Den forskningskompetente underviser formidler ikke blot viden forstået som en 'blind' videregivelse af viden fra andre, men er i stand til at forholde sig kritisk til, hvordan og under hvilke forudsætninger viden er skabt, hvilke grænser der er for den viden, og hvordan én type viden adskiller sig fra andre typer af viden. 
Forskningsbaseret undervisning i UC-sektoren - hvad og hvordan?

Udover et undervisningsperspektiv kan forskningskompetente undervisere også bidrage til at videreudvikle og kvalitetssikre det omfattende samarbejde med praksis og borgere, der allerede nu finder sted. Samarbejdet sker dels via praktikforløb og ved videreuddannelse (som $\mathrm{fx}$ aktionslæringsforløb), og dels via konsulentrådgivning, der kan systematiseres og kvalificeres via en stærkere tilknytning til de enkelte forskningsafdelinger. UC'erne har en lang og bred erfaring med praksis qua sin formålsparagraf, hvilket bevirker, at underviserkulturen er vant til at se bredde i både forsknings- og praksis/borgersamarbejde, snarere end at være fagfagligt smal og specialiseret.

Sidst men ikke mindst har forskningskompetente undervisere en særlig praksisbaseret insiderviden, som måske er deres største undervisningsmæssige aktiv. Undervisere, som kender en disciplin "indefra", har, også selv om de underviser uden for deres eget forskningsfelt, et særligt kendskab til, hvad der er mere eller mindre vigtigt, hvad der skal tages med et gran salt, selv om det står i lærebøgerne, og hvordan man faktisk arbejder inden for disciplinen, hvilket ofte er forskelligt fra de idealer, som udenforstående kender. Det gør det muligt at give nyttige "staldtips" og andet, som kan tjene til at udvikle de studerendes professionelle færdigheder. Professionalismen viser sig ved, at man ikke bare gør tingene "efter bogen", sådan som dygtige amatører vil gøre det, men med den særlige fingerspids- og situationsfornemmelse, der kendetegner trænede praktikere. Hvorvidt forskningskompetente undervisere faktisk formår at formidle deres insiderviden er selvfølgelig et åbent spørgsmål, idet det også kræver pædagogiske evner, ligesom der kan være tale om tavs viden, som vanskeligt lader sig eksplicitere fuldstændigt. Men selv om den måske ikke er en tilstrækkelig betingelse, så er den praksisbaserede insiderviden en nødvendig betingelse for vellykket undervisning i en videnskabeligt funderet disciplin.

Styrken ved at have forskningskompetente undervisere med stort praksiskendskab og bred samarbejdserfaring søger UC-sektoren naturligvis også at få mulighed for at bruge til at udvide sektorens eget uddannelsesområde, fx ved at få mulighed for at udbyde masteruddannelser (http://danskeprofessionshøjskoler.dk/). UC'erne argumenterer for, at "Masteruddannelser på professionshøjskolerne er nødvendige i den sammenhæng, da de i højere grad løfter kompetencerne i professionen og ikke ud af professionen". Udbuddet af undervisning på masterniveau kræver minimum en ph.d.-grad, altså forskningskompetente undervisere, hvilket UC-sektoren også argumenterer for som en mulighed, idet "sektorens igangværende FoU kapacitetsopbygning understøtter målet om inden for nogle år at udbyde masteruddannelser til gavn for professionerne" (http://danskeprofessionshøjskoler.dk/).

En aktiv strategi for brug af forskningskompetente undervisere udadtil i UC-sektoren kræver imidlertid også, at løn og arbejdsvilkår indadtil er interessante for forskningskompetente undervisere. UC'erne er forpligtede på at uddanne ph.d.er, hvilket naturligt er en omkostningstung opgave. Som skitseret ovenfor ligger der fremadrettet nogle væsentlige forskningsbaserede opgaver i UC-sektoren, der vil kunne løses mest kvalificeret ved en videns- og forsknings- tung indsats, der er knyttet tæt til og løses i samarbejde med praksis. Det er derfor nødvendigt at tildele forskningskompetente undervisere i UC-sektoren attraktive vilkår for at fastholde så mange færdiguddannede ph.d.er som muligt, for at UC-sektoren får fuldt udbytte af de dyre, men forskningskompetente undervisere.

Udover løn og arbejdsvilkår er attraktive arbejdsopgaver også nødvendige i en fastholdelsesstrategi. Forskerkompetencer kan naturligvis bruges til de eksisterende arbejdsopgaver, undervisning og et tæt samarbejde i og med praksis, som skitseret ovenfor, men forskning er også principielt international, hvilket betyder, at forskningskompetente undervisere nødvendigvis må arbejde og samarbejde internationalt for hele tiden at være opdateret på den nyeste viden og på de nyeste metoder inden for deres forskningsfelt. Disse forskningsmiljøer får ph.d.-stipendiater kendskab til i deres uddannelsesforløb, idet et ph.d.-projekt dels skal forankres på et universitet, dels ligger der et såkaldt miljøskifte indlejret i et ph.d.-forløb. Miljøskiftet har netop til hensigt at styrke den ph.d.-studerendes internationale samarbejde med henblik på at kvalificere egen forskning. En investering $i$ et fortsat forskningssamarbejde, både nationalt og internationalt, vil derfor bidrage til at gøre UC-sektoren til en attraktiv arbejdsplads for dygtige forskningskompetente undervisere.

UC'erne som efternøler eller rollemodel? Det kan virke, som om UC'erne med kravet om forskningsbaseret undervisning og selvstændig forskningsproduktion skal nærme sig det, der har været universiteterne særkende og dermed bevæge sig ind på et område, hvor de 
Tema: Kultur og civilisering

umiddelbart har dårligere forudsætninger, og hvor det er nødvendigt at skele til de traditionelle forskningsinstitutioner for at finde inspiration. Det kan give anledning til usikkerhed og utilfredshed, og man kan finde tegn på noget, der ligner et mindreværdskompleks i dele af UC-miljøet.

Hæfter man sig ved kravet om, at UC'erne skal producere en særlig form for forskning - at det drejer sig om "praksisnære og anvendelsesorienterede forsknings- og udviklingsaktiviteter" stiller sagen sig imidlertid anderledes. Også universiteterne er som nævnt under stigende pres for at producere forskning, som er relevant for løsningen af aktuelle samfundsproblemer. Forskernes egne interesser går på mange måder i samme retning. Det er for simpelt at se universiteterne som repræsentanter for modus 1- og UC'erne for modus 2-forskning. Modus 2-forskning er på en måde blevet altdominerende, om end i meget forskellige afskygninger. Næsten alle former for forskning forventes, direkte eller indirekte, at indgå i et samspil med det omgivende samfund. Et markant tegn på denne udvikling er, at selv Grundforskningsfonden, der om nogen kunne forventes at holde fast i idealet om videnskab for videnskabens egen skyld, bevidst har opgivet skellet mellem grund- og anvendt forskning, og åbent bekender sig til et ideal om forskning, der er grundlæggende, men også anvendelig eller på anden måde praksisnær; i stedet for "grundforskning" foretrækker fonden derfor nu udtrykket "frontforskning" (se http://dg.dk/centers-of-excellence/ hvad-er-et-center/).

I denne situation, hvor de traditionelle forskningsinstitutioner må eksperimen- tere med nye forsknings- og undervisningstyper og styrke båndene til det omgivende samfund, fremstår UC'erne som potentielle rollemodeller. De er så at sige født som modus 2-institutioner med et klart fokus på løsningen af konkrete samfundsopgaver, med tætte bånd til aftagerinstitutioner og tradition for at kombinere praktiske og teoretiske uddannelseselementer. De synes endog at have fordele, når det gælder om at bedrive undervisningsbaseret forskning - forskning der inddrager de studerende og indgår som en del af de studerendes undervisning - idet de studerende kan forventes at have interesse for og undertiden også førstehåndskendskab til det praksisfelt, der skal udforskes. Den viden, som opnås via forskningen, må formodes at have en direkte relevans for de studerende, således at feedbackkredsløbet mellem forskning og undervisning bliver effektivt og overskueligt. Set i forhold hertil har universiteterne betydelige ulemper i form af uklare og $\mathrm{i}$ bedste fald komplekse sammenhænge mellem uddannelsesindhold, forskningsopgaver og forskellige målsætninger.

Det betyder naturligvis ikke, at forskningsbaseret undervisning ikke udgør en stor udfordring for UC-sektoren. Som vi har påpeget, skal rammebetingelser som løn, arbejdsvilkår og arbejdsopgaver tilpasses de nye udfordringer. I en tid med resurseknaphed er dette langt fra nogen selvfølge.

Man skal i det hele taget vare sig for at idealisere. UC'erne er i princippet oplagte rollemodeller, men i praksis ikke nødvendigvis så privilegerede. Således er det tænkeligt, at de studerende umiddelbart vil være mindre motiverede for at engagere sig i forskningsrelaterede aktiviteter, om end dette også må formodes at afhænge af, hvor umiddelbart praksisrelevant den pågældende forskning er. Det må heller ikke glemmes, at anvendelsesorienteret og praksisnær forskning også kræver solide akademiske færdigheder, ligesom forskningsbaseret undervisning stiller særlige krav til både undervisere og studerende. Selv om forskningskompetente undervisere kan være med til at løfte kvaliteten af undervisningen, sådan som det er hensigten, kan der være noget om den kritik af forskningsbaseret undervisere som skeptikerne (f.eks. Newman, men også bl.a. Max Weber) gennem tiden har rejst: forskningskompetence og pædagogiske færdigheder går ikke nødvendigvis hånd $\mathrm{i}$ hånd; vidensproduktion og vidensformidling kan befrugte, men også undertiden stå i vejen for hinanden.

Alligevel er der grund til at se udviklingen, ikke blot som en udefra påtvungen belastning eller som en grund til et mindreværdskompleks, men snarere som en mulighed for at udvikle og udfolde det potentiale, der allerede ligger i en institutionstype som UC'erne. Her burde der for alvor være mulighed for at forskning og undervisning kan befrugte hinanden og bidrage til og tage pejling af det omgivende samfund. Det bliver spændende at se, hvorvidt de muligheder faktisk lader sig realisere. 
Forskningsbaseret undervisning i UC-sektoren - hvad og hvordan?

\section{REFERENCES}

ACE Denmark (2011): "Vejledning til ansøgning om akkreditering og godkendelse af eksisterende universitetsuddannelser" (2. udgave) (kkr.dk/wp-content/uploads/akkr/Vejledning_ eksisterende_uddannelser_010211.pdf).

Andersen, H. L. (2010). » Constructive alignment «og risikoen for en forsimplende universitetspædagogik. Dansk Universitetspœdagogisk Tidsskrift, 5(9), 30-35.

Brew, A. (2012). Teaching and research: New relationships and their implications for inquiry-based teaching and learning in higher education. Higher Education Research and Development, 31(1), 101-101-114.

Clark, W. (2006). Academic Charisma and the Origins of the Research University. Chicago: The University of Chicago Press.

Danske Professionshøjskoler: www.uc-dk.dk/da/presse-ogdebat/debatindl\%C3\%A6g/88-nye-ukategoriseret/484-ny1\%C3\%A6reruddannelse-er-p\%C3\%A5-forkant-med-kritik-fraproduktivitetskommissionen.html

Det Kongelige Danske Videnskabernes Selskab, Kvalitet $i$ universitetsuddannelserne - forskningsbaseret undervisning. Hvidbog, Forskningspolitisk Årsmøde 2011.

Frascati Manual, (2002): Proposed Standard Practice for Surveys on Research and Experimental, Development, OECD.

Kirschner, P. A., Kirschner, P. A., Sweller, J., \& Clark, R. E. (2006). Why minimal guidance during instruction does not work: An analysis of the failure of constructivist, discovery, problembased, experiential, and inquiry-based teaching. Educational Psychologist, 41(2), 75-75-86.

Kjærsdam, Finn, (26.12.2010): Kommentar (Om forksningsbasering), Politiken.

LBK: Bekendtgørelse af lov om professionshøjskoler for videregående uddannelser, 2014, nr. 936 af 25/08/2014, www.retsinformation.dk/forms/r0710.aspx?id=164459

Newman, J. H. (1852/1873). The Idea of a University. London: Longman Greens \& Co.
Pawelleck, A. (2013). Research-based teaching and learning (RBTL) - a paradigm for enhancing teaching and learning at research universities. REDU: Revista De Docencia Universitaria, 11(3), 159-159-172.

Qvortrup, L. (2015). Det ved vi om forskningsinformeret lœringsledelse. Frederikshavn: Dafolo.

Siggaard Jensen, H, (2001): Undervisningsministeriet, 3, http://udd.uvm.dk/200103/udd03-4.htm.

UFM: Uddannelses- og Forskningsministeriet, (2016):

http://ufm.dk/forskning-og-innovation/statistik-og analyser/ hvad-er-forskning-innovation-og-udvikling

Ulriksen, L. (2014). In Ulriksen L. (Ed.), God undervisning på de videregående uddannelser: En forskningsbaseret brugsbog, Frydenlund.

Willcoxson, L. (2011). Enhancing the research-teaching nexus: Building teaching-based research from research-based teaching. International Journal of Teaching and Learning in Higher Education, 23(1), 1-1-10. 